\title{
ANALISIS INTENSITAS PENCAHAYAAN PADA LAPANGAN PLANET FUTSAL RUMBAI PEKANBARU
}

\author{
Fajar Okasantoso Hutauruk ${ }^{1}$, Atmam ${ }^{2}$, Usaha Situmeang ${ }^{3}$ \\ ${ }^{1,2,3}$ Program Studi Teknik Elektro, Fakultas Teknik, Universitas Lancang Kuning \\ Jl. Yos Sudarso km. 8 Rumbai, Pekanbaru, Telp. (0761) 52324 \\ Email: Fajarhutauruk@unilak.ac.id, atmam@unilak.ac.id, usahasitumeang@unilak.ac.id
}

\begin{abstract}
ABSTRAK
Lapangan futsal indoor planet futsal merupakan salah satu fasilitas olah raga yang ada di daerah Rumbai. Sebagaimana fungsi dari lapangan futsal indoor ini, maka penggunaan pada malam hari tentunya menggunakan pencahayaan buatan. Pencahayaan buatan yang sudah terpasang berdasarkan pengalaman pengguna fasilitas ini masih kurang memuaskan dalam arti kurang terang. Pendapat tersebut diperkuat berdasarkan fakta hasil pengukuran nilai iluminasi lapangan futsal indoor kurang dari 100 lux. Maka pada peneliian ini, dilakukan analisa intensitas penerangan lapangan planet futsal Rumbai Pekanbaru dalam melakukan aktivitas permainan futsal pada malam hari, membandingkan hasil intensitas penerangan dengan standart penerangan lapangan dan menghitung energi listrik pencahayaan yang digunakan pada lapangan planet futsal Rumbai Pekanbaru. Dari hasil penelitian diperoleh intensitas penerangan rata-rata untuk tiap-tiap lapangan planet futsal Rumbai Pekanbaru sebesar 52,95 lux pada lapangan 1, 50,26 lux pada lapangan 2, 54,28 lux pada lapangan 3 dan 54,16 lux pada lapangan 4 . Sehingga intensitas penerangannya masih rendah dan belum memenuhi rekomendasi pengukuran standart SNI 16-7062-2004.
\end{abstract}

Kata Kunci: Intensitas penerangan, pengaturan pencahayaan ruangan

\begin{abstract}
Futsal indoor futsal field is one of the sport facilities in Rumbai area. As the function of this indoor futsal field, then the use at night of course using artificial lighting. Artificial lighting that has been installed based on the user experience of this facility is still less satisfactory in the sense of lack of light. The opinion is reinforced based on the facts of indoor illumination field value measurement value less than 100 lux. So in this study, the intensity analysis of field lighting futsal Rumbai Pekanbaru in performing futsal game activities at night, comparing the results of the intensity of lighting with field lighting standard and calculate the electrical energy of lighting used in the field futsal planet Rumbai Pekanbaru. From result of research obtained by average lighting intensity for each futsal planet field Rumbai Pekanbaru equal to 52,95 lux at field 1, 50,26 lux in field 2, 54,28 lux at field 3 and 54,16 lux on field 4 So that the intensity of lighting is still low and has not fulfilled the standard measurement recommendation SNI 16-7062-2004.
\end{abstract}

Keywords: Intensity of lighting, room lighting arrangement

\section{PENDAHULUAN}

Lapangan olahraga indoor adalah sebuah bangunan yang berisikan fasilitas tempat olahraga tertutup. Cabang olahraga yang biasanya diselenggarakan dalam lapangan indoor antara lain : futsal, tenis meja, bulu tangkis, bowling, basket, dan sebagainya. Lapangan olahraga indoor dituntut untuk memberikan pencahayaan yang ideal sesuai dengan standart rekomendasi SNI 16-7062-2004.

Lapangan planet futsal indoor Rumbai Pekanbaru adalah bangunan yang dibangun di daerah kecamatan Rumbai Pekanbaru yang menyediakan tempat olahraga futsal. Di lapangan planet futsal Rumbai Pekanbaru ini, permainan futsal biasanya dilakukan siang dan malam hari, sehingga pencahayaan yang digunakan pada saat malam hari adalah pencahayaan buatan yang berasal dari lampu. Lapangan planet futsal indoor Rumbai Pekanbaru membutuhkan tingkat pencahayaan berkisar 200-400 lux sesuai standart rekomendasi SNI 16-7062-2004. Sistem pencahayaan dalam ruangan olahraga perlu diperhatikan karena berpengaruh pada kenyamanan visual dan keamanan 
orang yang sedang melakukan olahraga maupun penonton pada ruangan tersebut. Pengukuran lapangan dilakukan untuk mengetahui data-data berupa dimensi ruangan, keadaan ruangan beserta spesifikasi lampu yang digunakan dibutuhkan untuk menganalisa kebutuhan pencahayaan pada ruangan tersebut.

Selain untuk memberikan kenyamanan visual dan keamanan bagi para pemain, dalam pertandingan olahraga, setidaknya lapangan futsal indoor planet futsal memiliki iluminasi sesuai standart rekomendasi SNI 16-7062-2004 yaitu minimal 200 lux. Aspek lain yang tidak kalah penting adalah konsumsi daya untuk pencahayaan. Pemilihan dan penempatan dari lampu yang digunakan akan mempengaruhi jumlah lampu yang digunakan, secara otomatis juga dapat menghemat konsumsi daya yang digunakan, yang sesuai dengan standar rekomendasi SNI 16-70622004 dan kebutuhan yang ada sehingga bisa memberikan kenyamanan bagi pemain maupun penonton.

\section{METODE PENELITIAN}

Metode penelitian yang digunakan dalam penelitian ini adalah :

1. Metode pengumpulan data

Metode yang digunakan pada proses pengumpulan data yaitu objek yang diteliti yaitu intensitas penerangan pada lapangan planet futsal Rumbai Pekanbaru dengan melakukan pengukuran kuat pencahayaan pada lapangan untuk mendapatkan data-data.

2. Metode Pengolahan data

Dari data yang diperoleh dari pengukuran kuat pencahayaan pada lapangan planet futsal Rumbai Pekanbaru, maka data-data tersebut digunakan untuk menghitung kebutuhan intensitas yang dibutuhkan.

3. Menganalisa data pengukuran

Dari data yang diolah maka selanjutnya dilakukan analisa data untuk mendapat nilai intensitas penerangan yang diperlukan dengan mensimulasikannya dengan software Dialux.

\section{Pencahayaan}

Pencahayaan merupakan salah satu faktor untuk mendapatkan keadaan lingkungan yang aman dan nyaman dan berkaitan erat dengan produktivitas manusia. Pencahayaan yang baik memungkinkan orang dapat melihat objek-objek yang dikerjakannya secara jelas dan cepat.

\section{Sistem Pencahayaan}

Sistem pencahayaan adalah suatu proses memberikan penerangan pada suatu ruangan dengan cara memasang atau memanfaat kan sumber cahaya yang ada. Sistem pencahayaan buatan yang sering dipergunakan secara umum dapat dibedakan atas 3 macam yakni (SNI 03 - 6575 - 2001) :

\section{Sistem Pencahayaan Merata}

Pada sistem ini iluminasi cahaya tersebar secara merata di seluruh ruangan. Sistem pencahayaan ini cocok untuk ruangan yang tidak dipergunakan untuk melakukan tugas visual khusus. Pada sistem ini sejumlah armatur ditempatkan secara teratur di seluruh langi-langit.

\section{Sistem Pencahayaan Terarah}

Pada sistem ini seluruh ruangan memperoleh pencahayaan dari salah satu arah tertentu. Sistem ini cocok untuk pameran atau penonjolan suatu objek karena akan tampak lebih jelas. Lebih dari itu, pencahayaan terarah yang menyoroti satu objek tersebut berperan sebagai sumber cahaya sekunder untuk ruangan sekitar, yakni melalui mekanisme pemantulan cahaya. Sistem ini dapat juga digabungkan dengan sistem pencahayaan merata karena bermanfaat mengurangi efek menjemukan yang mungkin ditimbulkan oleh pencahayaan merata.

3. Sistem Pencahayaan Setempat

Pada sistem ini cahaya dikonsentrasikan pada suatu objek tertentu misalnya tempat kerja yang memerlukan tugas visual. Sistem pencahayaan ini sangat bermanfaat untuk:

a. Memperlancar tugas yang memerlukan visualisasi teliti.

b. Mengamati bentuk dan susunan benda yang memerlukan cahaya dari arah tertentu.

c. Melengkapi pencahayaan umum yang terhalang mencapai ruangan khusus yang ingin diterangi.

d. Tingkat pencahayaan yang lebih tinggi diperlukan untuk orang tua atau yang kemampuan penglihatannya sudah berkurang.

Dalam sistem pencahayaan perlu perhitungan yang tepat bagi seorang perangcang, pelaksana ataupun pemilik atau pengelola gedung dalam merancang, mengoperasikan dan memelihara sistem pencahayaan. Hal ini dilakukan agar diperoleh sistem pencahayaan buatan yang sesuai dengan syarat kesehatan, kenyamanan, keamanan, dan memenuhi ketentuan yang berlaku untuk bangunan gedung.

\section{Penyebaran Cahaya}

Penyebaran Cahaya dari suatu cahaya bergantung pada konstruksi sumber cahaya itu sendiri dan armature yang digunakan. Sebagian besar cahaya yang direspon mata tidak langsung di sumber cahaya, tetapi setelah dipantulkan atau melalui benda yang tembus cahaya. Jika kita berada dalam suatu ruang yang ada sumber cahaya dari sebuah lampu, maka ada dua sumber cahaya, yaitu sumber cahaya primer yang berasal dari lampu tersebut dan sumber cahaya sekunder yang merupakan pantulan dari fiting lampu tersebut. Dari dinding-dinding di sekitar ruangan [1]. 
Untuk penerangan, secara garis besar penyebaran cahaya ada 3 macam yaitu penyebaran langsung, tidak langsung atau campuran [1].

a. Penerangan Langsung

Efisiensi penerangan langsung sangat baik. Cahaya yang dipancarkan suber cahaya seluruhnya diarahkan kebidang yang harus diberi penerangan ; langit-langit hampir tidak ikut berperan. Akan tetapi sistem penerangan ini menimbulkan bayang-bayang yang tajam.

b. Penerangan Tidak Langsung

Pada sistem penerangan tak langsung cahayanya dipantulkan oleh langit-langit dan dinding. Warna langit-langit dan dinding ini harus terang bayangbayang hampir tidak ada lagi. Penerangan tak langsung antara lain digunakan di ruang-ruang untuk membaca, menulis dan untuk melakukan pekerjaan-pekerjaan halus lainnya.

c. Penerangan Campuran

Efisiensi penerangan ini lebih rendah dari pada efisiensi kedua sistem penerangan langsung dan penerangan tidak langsung. Sebagian dari cahaya sumber-sumber cahaya sekarang diarahkan kedinding dan langit-langit. Pembentukan bayangan kilaunya banyak berkurang. Penerangan campuran digunakan di sekolah, di ruang-ruang kantor dan di tempat kerja.

\section{Hukum Penerangan}

Satuan-satuan penting yang digunakan dalam teknik penerangan antara lain [2] :

$\begin{array}{llll}\text { 1. Sudut ruang } & \mathrm{W} & \text { Steradian }(\mathrm{Sr}) \\ \text { 2. } & \text { Intensitas cahaya } & \mathrm{I} & \text { Candela }(\mathrm{cd}) \\ \text { 3. } & \text { Fluks cahaya } & \mathrm{F}(\Phi) & \text { lumen }(\mathrm{Lm}) \\ \text { 4. Luminasi } & \mathrm{L} & \left(\mathrm{cd} / \mathrm{m}^{2}\right) \\ \text { 5. } & \text { Iluminasi } & \mathrm{E} & \text { lux }(\mathrm{lx})\end{array}$

\section{Hukum Kosinus}

Apabila sebuah lampu dengan intensitas cahaya I kandela ke segala arah dibawah bidang mendatar digantung di atas permukaan mendatar, iluminasi yang di hasilkan pada seberang titik B pada pemukaan tersebut seperti pada gambar 1 [3].

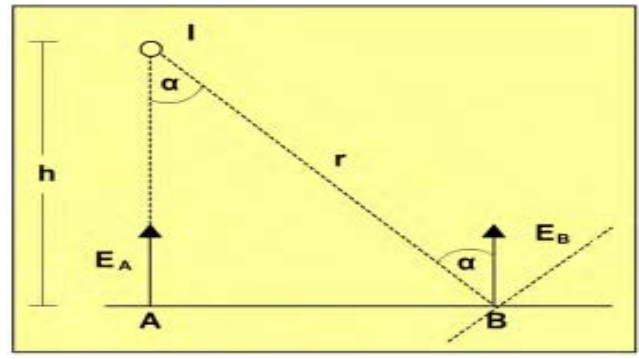

Gambar 1. Kurva kosinus

\section{Fluks Cahaya atau Arus Cahaya}

Aliran rata-rata energi cahaya adalah arus cahaya atau fluks cahaya. Arus cahaya didefinisikan sebagai jumlah total cahaya yang dipancarkan oleh sumber cahaya setiap detik. Besarnya arus cahaya dengan satuan lumen (lm) dinyatakan dengan persamaan 1 [4].

$$
\Phi=\frac{Q}{t} \quad I m
$$

Keterangan :

$\Phi=$ fluks cahaya dalam lumen (lm)

$Q=$ energi cahaya dalam lumen jam atau lumen detik

$t$ = waktu dalam jam atau detik

\section{Intensitas Penerangan}

Menurut sejarah, sumber cahaya buatan adalah lilin (candela) seperti gambar 2. Candela dengan singkatan Cd ini merupakan satuan Intensitas Cahaya (I) dari sebuah sumber yang memancarkan energi cahaya ke segala arah [5].

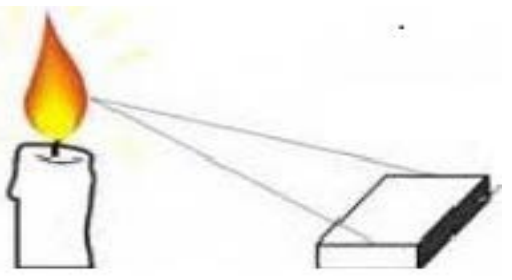

Gambar 2. Lilin yang menyinari buku

Intensitas penerangan atau iluminasi disuatu bidang ialah flux cahaya yang jatuh pada $1 \mathrm{~m}^{2}$ dari bidang itu. Satuan untuk intensitas penerangan ialah lux (lx), dan lambangnya (E). Kalau suatu bidang yang luasnya $\mathrm{A} \mathrm{m}^{2}$ pada gambar 3 , diterangi dengan lumen, maka intensitas penerangan (E) rata-rata dibidang itu sama dengan persamaan 2 [1].

$$
E=\frac{\Phi}{A} \quad \operatorname{lux}
$$

Keterangan :

$E$ = intensitas penerangan (lux)

$\Phi=$ fluks cahaya (lumen)

$A=$ luas bidang kerja $\left(\mathrm{m}^{2}\right)$

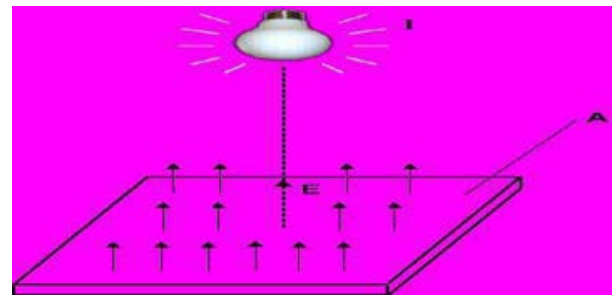

Gambar 3. Iluminasi 
Karena adanya faktor pemakaian dan depresiasi akibat debu pada luminaire dan lampu, maka persamaan tersebut harus dikalikan dengan coefficient of utilization (CU) dan light-loss factor (LLF). Formula tersebut dinyatakan lebih jelas dengan persamaan $3[6]$ :

$$
E=\frac{N \times n \times L L \times C U \times L L F}{A} l u x
$$

Keterangan :

$N=$ jumlah luminaire

$n \quad=$ jumlah lampu tiap luminaire

$L L \quad=$ lumen yang dihasilkan tiap lampu

$C U=$ coefficient of utilization

$L L F=$ light-loss factor

A = luas bidang $\left(\mathrm{m}^{2}\right)$

\section{Koefisien Pemakaian / Coeficient of Untization} (CU)

Menurut [7] yang mempengaruhi faktor CU adalah :

1. Arus cahaya yang sampai dibidang kerja (the level of interest)

2. Distribusi cahaya oleh luminaire

3. Ketinggian oleh luminaire diatas bidang kerja

4. Proporsi ruang

5. Reflektansi permukaan

Faktor Kehilangan Cahaya / Light Loss Factor (LLF)

Kehilangan cahaya pada sumber penerangan dipengaruhi 2 faktor yaitu :

1. Penurunan kemampuan sumber penerangan (lampu dan armatur) karena umur pemakaian.

2. Pengotoran terhadap armaturnya, dapat disebabkan pengotoran atau perubahan sifat armatur.

\section{HASIL DAN PEMBAHASAN}

\subsection{Denah dan Ukuran Lapangan}

Lapangan planet futsal Rumbai Pekanbaru merupakan bangunan baru, dengan model bangunan setengah beton seperti pada gambar 4 , yang memiliki luas keseluruhan bangunan $2.400 \mathrm{~m}^{2}$,

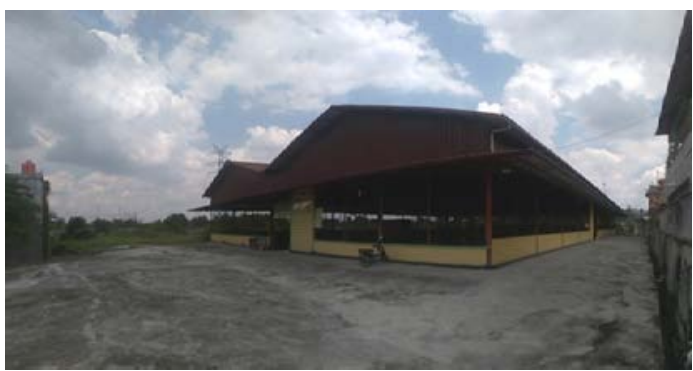

Gambar 4. Gelanggang olahraga planet futsal Rumbai Pekanbaru
Terdiri dari 4 lapangan futsal seperti pada gambar 5 .

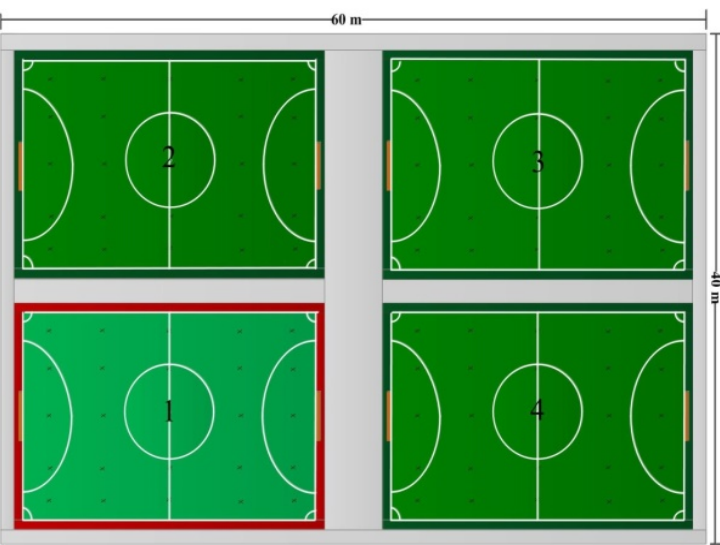

Gambar 5. Denah lapangan planet futsal Rumbai Pekanbaru

Untuk masing-masing lapangan memiliki ukuran $16 \times 26$ m seperti pada gambar 6 , dalam lapangan di pasang 25 buah penerangan buatan (lampu) diberi tanda (X).

Keterangan :

$\mathbf{X}=$ Lampu Compact Flourescent Lamps (CFL) $70 \mathrm{~W} / 4400 \mathrm{~lm}$

$\mathbf{X}=$ Lampu Compact Flourescent Lamps (CFL) $52 \mathrm{~W} / 3230 \mathrm{~lm}$

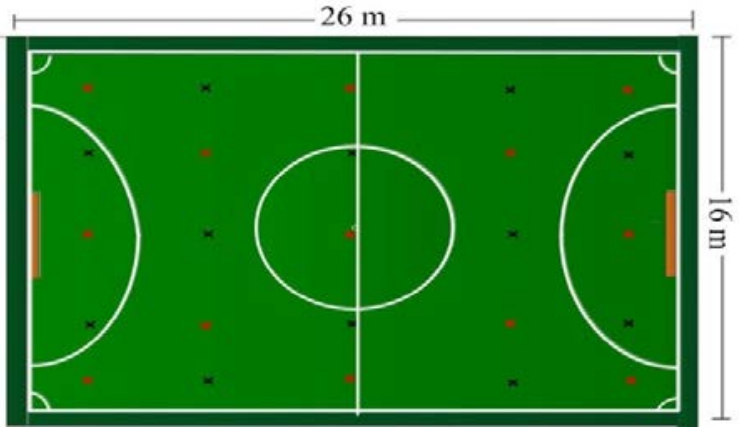

Gambar 6. Ukuran lapangan planet futsal Rumbai Pekanbaru

Hasil pengukuran tingkat pencahayaan rata-rata pada lapangan planet futsal Rumbai Pekanbaru dengan menggunakan luxmeter (Lutron Light meter type LX113S) pada kondisi eksisting pada masing-masing lapangan seperti pada tabel 1 .

Tabel 1. Hasil Pengukuran Rata- rata Tingkat Pencahayaan

\begin{tabular}{|c|c|c|}
\hline No & Ruangan & $\begin{array}{c}\text { Tingkat Pencahayaan Hasil } \\
\text { Pengukuran (Lux) }\end{array}$ \\
\hline 1 & Lapangan 1 & 52,95 \\
\hline 2 & Lapangan 2 & 50,26 \\
\hline 3 & Lapangan 3 & 54,28 \\
\hline 4 & Lapangan 4 & 54,16 \\
\hline
\end{tabular}




\subsection{Tingkat Pencahayaan Ruangan}

Pada penelitian ini memerlukan adanya datadata standart yang nantinya akan digunakan sebagai penunjang penelitian adapun standart rekomendasi SNI 16-7062-2004 pada lapangan olah raga seperti pada tabel 2 berikut :

Tabel 2 Standart Pencahayaan Olahraga

\begin{tabular}{|l|c|c|}
\hline \multirow{2}{*}{\multicolumn{1}{|c|}{ Jenis Olahraga }} & \multicolumn{2}{c|}{ Iluminasi (lux) } \\
\cline { 2 - 3 } & Latihan & Pertandingan \\
\hline Sepak bola/Futsal & 75 & 200 - 600 \\
\hline Bola tangan & 75 & 400 \\
\hline Bola Volly (indoor) & 200 & 400 \\
\hline Badminton (indoor) & 200 & 400 \\
\hline Hoky (indoor/outdoor) & 200 & 400 \\
\hline Renang (indoor/outdoor) & 200 & 400 \\
\hline Polo air(indoor/outdoor) & 200 & 400 \\
\hline Tenis (indoor/outdoor) & 200 & $400-600$ \\
\hline Pacu Kuda & 100 & 150 \\
\hline Loncat Indah (indoor) & 150 & 400 \\
\hline Bowling & 200 & 200 \\
\hline
\end{tabular}

\subsection{Data Teknis dan Spesifikasi Lampu} Terpasang

Luminair atau pencahayaan yang terpasang di lapangan planet futsal Rumbai Pekanbaru terdiri dari 25 buah lampu pada masing-masing lampu, total lampu yang terpasang untuk semua lapangan $4 \times 25$ buah lampu dengan dua jenis produk Philips essential 70 dan Philips helix 52 Watt yang dipasang tergantung dengan ketinggian $6 \mathrm{~m}$ dari permukaan lantai dan arah penyinarannya vertikal kebawah. Data teknis lampu yang dipasang pada lapangan planet futsal Rumbai Pekanbaru seperti pada tabel 3 berikut :

Tabel 3. Data Teknis Lampu

\begin{tabular}{|l|c|c|c|c|}
\hline Jenis Lampu & Jumlah & $\begin{array}{c}\text { Daya Lampu } \\
\text { (Watt) }\end{array}$ & $\begin{array}{c}\text { Daya Total } \\
\text { (Watt) }\end{array}$ & $\begin{array}{c}\text { Luminaus } \\
\text { fluk (lm) }\end{array}$ \\
\hline Philips Essential & 52 & 70 & 2800 & 4400 \\
\hline Philips Helix & 48 & 52 & 2080 & 3230 \\
\hline
\end{tabular}

\subsection{Pengambialan Data dan Kuat Pencahayaan di Lapangan Planet Futsal Rumbai Pekanbaru}

Lapangan futsal yang terletak di gedung planet futsal Rumbai Pekanbaru ini memiliki luas total 2400 $\mathrm{m}^{2}$. Terdiri dari 4 unit lapangan futsal yang masingmasing memiliki ukuran $16 \times 26$ meter. Untuk pengukuran intensitas pencahayaan menggunakan alat ukur luxmeter merk Lutron Light meter type $L X$ $113 S$ alat ini sudah dikalibrasi dan dalam kondisi baik. Adapun bentuk fisik alat ukur yang digunakan tersebut seperti gambar 7 .

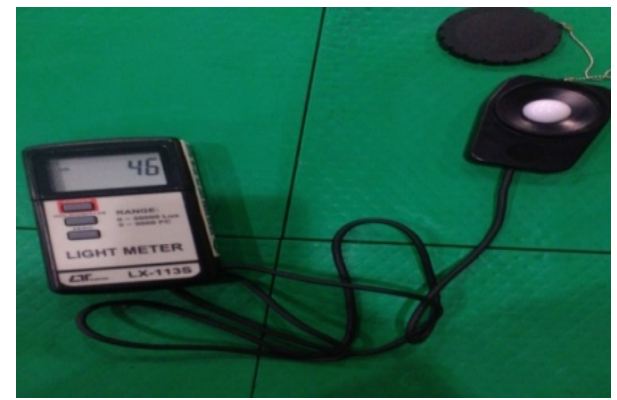

Gambar 7. Luxmeter Lutron Light meter type LX-113S

Untuk pengukuran kuat pencahayaan digunakan metode pengukuran dengan acuan SNI 167062-2004. Luas masing-masing lapangan planet futsal Rumbai Pekanbaru $416 \mathrm{~m}^{2}$, maka menurut acuan standar SNI tersebut, harus dibuat titik potong garis horizontal panjang ruang dan garis vertikal lebar ruang pada jarak $6 \mathrm{~m}$. Pengukuran akan dilakukan pada titik-titik potong tersebut. Titik-titik pengukuran intensitas pencahayaan pada masing-masing lapangan sesuai acuan standart SNI 16-7062-2004 seperti pada gambar 8 .

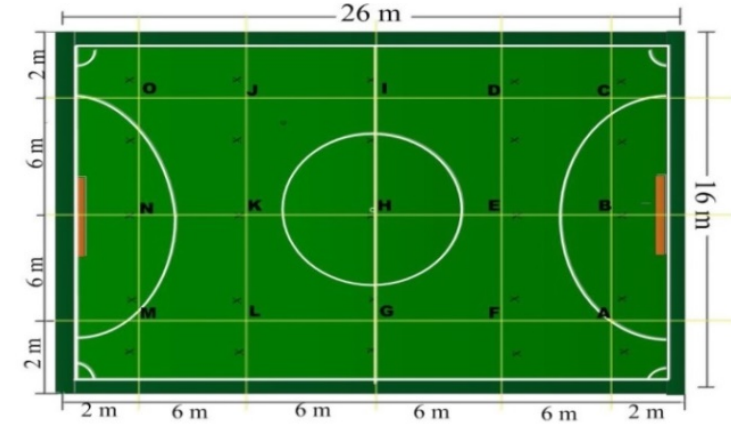

Gambar 8. Titik-titik pengukuran

Data hasil pengukuran kuat pencahayaan pada masing-masing lapangan seperti pada tabel 4, sampai dengan tabel 7 adapun pengambilan data ada beberapa Pengukuran diantaranya :

a. Pengukuran 1 pada tanggal 28 Maret 2017 dimulai dari jam 19.00 sampai 20.15 Wib dengan kondisi diluar turun hujan.

b. Pengukuran 2 pada tanggal 28 Maret 2017 dimulai dari jam 23.00 sampai 00.15 Wib dengan kondisi diluar turun hujan.

c. Pengukuran 3 pada tangga 13 Juni 2017 dimulai dari jam 21.00 sampai 22.15 Wib dengan kondisi normal. 
Tabel 4. Data Pengukuran Lapangan 1

\begin{tabular}{|c|c|c|c|c|}
\hline \multirow{2}{*}{ Titik } & \multicolumn{3}{|c|}{ Iluminasi (lux) } & \multirow{2}{*}{$\begin{array}{c}\text { Rata-rata } \\
\text { (lux) }\end{array}$} \\
\cline { 2 - 5 } & Pengukuran 1 & Pengukuran 2 & Pengukuran 3 & \\
\hline A & 56 & 45 & 46 & 49 \\
\hline B & 51 & 60 & 56 & 55,66 \\
\hline C & 54 & 51 & 52 & 52,33 \\
\hline D & 46 & 57 & 51 & 51,33 \\
\hline E & 46 & 54 & 54 & 51,33 \\
\hline F & 46 & 48 & 46 & 46,66 \\
\hline \hline G & 43 & 52 & 50 & 48,33 \\
\hline H & 48 & 56 & 50 & 51,33 \\
\hline I & 48 & 58 & 55 & 53,66 \\
\hline J & 49 & 56 & 53 & 52,66 \\
\hline K & 60 & 60 & 58 & 59,33 \\
\hline L & 58 & 56 & 57 & 57 \\
\hline M & 63 & 57 & 55 & 58,33 \\
\hline N & 54 & 52 & 49 & 51,66 \\
\hline O & 56 & 56 & 55 & 55,66 \\
\hline & \multicolumn{5}{|l}{ Rata-rata total } & & 52,95 \\
\hline & & & \\
\hline
\end{tabular}

Tabel 5. Data Pengukuran Lapangan 2

\begin{tabular}{|c|c|c|c|c|}
\hline \multirow{2}{*}{ Titik } & \multicolumn{3}{|c|}{ Iluminasi (lux) } & \multirow{2}{*}{$\begin{array}{c}\text { Rata-rata } \\
\text { (lux) }\end{array}$} \\
\hline & Pengukuran 1 & Pengukuran 2 & Pengukuran 3 & \\
\hline $\mathrm{A}$ & 47 & 40 & 45 & 44 \\
\hline B & 54 & 57 & 50 & 53,66 \\
\hline $\mathrm{C}$ & 58 & 48 & 42 & 49,33 \\
\hline $\mathrm{D}$ & 48 & 39 & 43 & 43,33 \\
\hline $\mathrm{E}$ & 42 & 55 & 50 & 49 \\
\hline $\mathrm{F}$ & 41 & 54 & 49 & 48 \\
\hline $\mathrm{G}$ & 51 & 60 & 56 & 55,66 \\
\hline $\mathrm{H}$ & 62 & 58 & 53 & 57,66 \\
\hline I & 63 & 48 & 48 & 53 \\
\hline $\mathrm{J}$ & 60 & 58 & 42 & 53,33 \\
\hline $\mathrm{K}$ & 49 & 45 & 37 & 43,66 \\
\hline $\mathrm{L}$ & 53 & 53 & 67 & 57,66 \\
\hline $\mathrm{M}$ & 53 & 48 & 48 & 49,66 \\
\hline $\mathrm{N}$ & 55 & 55 & 46 & 52 \\
\hline $\mathrm{O}$ & 51 & 50 & 52 & 44 \\
\hline \multicolumn{3}{|c|}{ Rata-rata total } & & 50,26 \\
\hline
\end{tabular}

Tabel 6. Data Pengukuran Lapangan 3

\begin{tabular}{|c|c|c|c|c|}
\hline \multirow{2}{*}{ Titik } & \multicolumn{3}{|c|}{ Iluminasi (lux) } & \multirow{2}{*}{$\begin{array}{c}\text { Rata-rata } \\
\text { (lux) }\end{array}$} \\
\cline { 2 - 5 } & Pengukuran 1 & Pengukuran 2 & Pengukuran 3 & \\
\hline A & 47 & 45 & 53 & 48,33 \\
\hline B & 62 & 62 & 58 & 60,66 \\
\hline C & 58 & 52 & 42 & 50,66 \\
\hline D & 57 & 58 & 57 & 57,33 \\
\hline E & 51 & 53 & 55 & 53 \\
\hline F & 56 & 52 & 49 & 52,33 \\
\hline G & 60 & 58 & 56 & 58 \\
\hline H & 60 & 54 & 55 & 56,33 \\
\hline I & 62 & 57 & 56 & 58,33 \\
\hline J & 61 & 58 & 55 & 58 \\
\hline K & 66 & 60 & 67 & 64,33 \\
\hline L & 46 & 45 & 51 & 47,33 \\
\hline M & 46 & 46 & 51 & 47,66 \\
\hline N & 54 & 57 & 50 & 53,66 \\
\hline O & 41 & 45 & 49 & 48,33 \\
\hline & \multicolumn{3}{|c|}{ Rata-rata total } & 54,28 \\
\hline
\end{tabular}

Tabel 7. Data Pengukuran Lapangan 4

\begin{tabular}{|c|c|c|c|c|}
\hline \multirow{2}{*}{ Titiik } & \multicolumn{3}{|c|}{ Iluminasi (lux) } & \multirow{2}{*}{$\begin{array}{c}\text { Rata-rata } \\
\text { (lux) }\end{array}$} \\
\cline { 2 - 5 } & Pengukuran 1 & Pengukuran 2 & Pengukuran 3 & \\
\hline A & 49 & 57 & 53 & 53 \\
\hline B & 54 & 52 & 48 & 51,33 \\
\hline C & 56 & 42 & 42 & 46,66 \\
\hline D & 55 & 45 & 47 & 49 \\
\hline E & 50 & 40 & 46 & 45,33 \\
\hline F & 48 & 51 & 48 & 49 \\
\hline G & 58 & 63 & 56 & 59 \\
\hline H & 59 & 59 & 55 & 57,66 \\
\hline I & 59 & 60 & 53 & 57,33 \\
\hline \hline J & 59 & 56 & 58 & 57,66 \\
\hline K & 49 & 57 & 52 & 52,66 \\
\hline L & 48 & 54 & 47 & 49,66 \\
\hline M & 50 & 47 & 47 & 48 \\
\hline N & 63 & 62 & 58 & 61 \\
\hline O & 62 & 61 & 56 & 53 \\
\hline & & Rata-rata total & & 52,68 \\
\hline
\end{tabular}

\subsection{Permasalahan Sistem Pencahayaan Pada Ruangan}

Sistem penerangan pada kondisi eksisting masih belum optimal, hal tersebut terlihat dari perbedaan tingkat pencahayaan kondisi eksisting masih jauh dibawah rekomendasi tingkat pencahayaan. Perbandingan Tingkat Pencahayaan hasil pengukuran dan Nilai Rekomendasi SNI 16-7062-2004 seperti pada tabel 8 .

Tabel 8. Perbandingan Tingkat Pencahayaan

\begin{tabular}{|c|c|c|c|c|}
\hline \multirow{2}{*}{ No } & Ruangan & $\begin{array}{c}\text { Hasil Pengukuran } \\
(\text { Lux })\end{array}$ & $\begin{array}{c}\text { Nilai Rekomendasi } \\
\text { (Lux) }\end{array}$ & $\begin{array}{c}\text { Selisih } \\
\text { (Lux) }\end{array}$ \\
\cline { 3 - 5 } & Lapangan 1 & 52,95 & 200 & -147.05 \\
\hline 2 & Lapangan 2 & 50,26 & 200 & -149.74 \\
\hline 3 & Lapangan 3 & 54,28 & 200 & -145.72 \\
\hline 4 & Lapangan 4 & 54,16 & 200 & -145.84 \\
\hline
\end{tabular}

\subsection{Analisa Kuat Pencahayaan}

Hasil pengukuran kuat pencahayaan pada tabel 4 sampai dengan tabel 7 lapangan planet futsal indoor Rumbai Pekanbaru disajikan dalam bentuk grafik, seperti pada gambar 9 sampai dengan gambar 13 berikut :

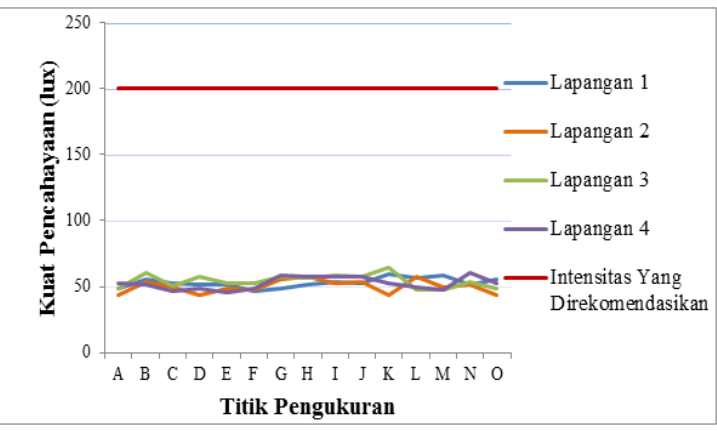

Gambar 9. Grafik kuat pencahayaan Seluruh lapangan 


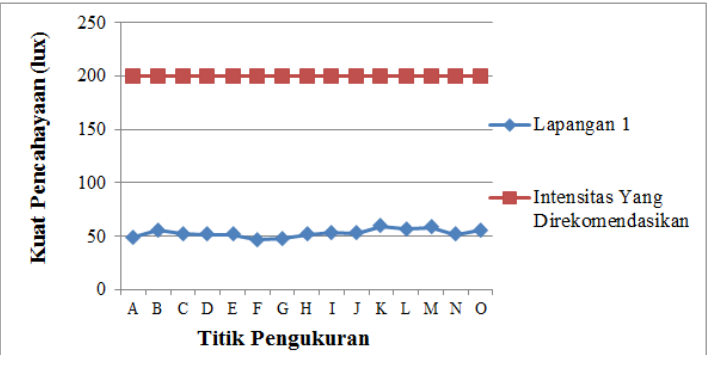

Gambar 10. Grafik kuat pencahayaan lapangan 1

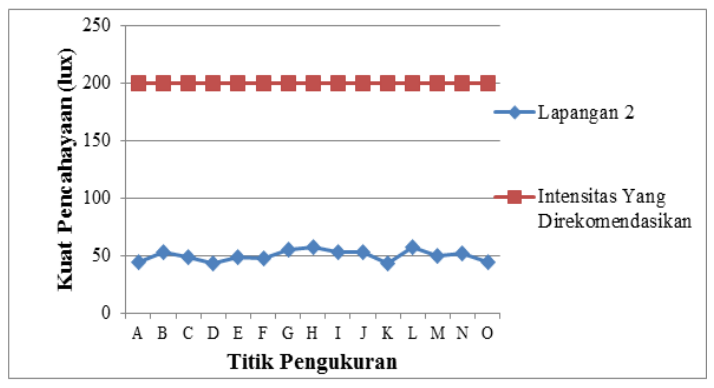

Gambar 11. Grafik kuat pencahayaan lapangan 2

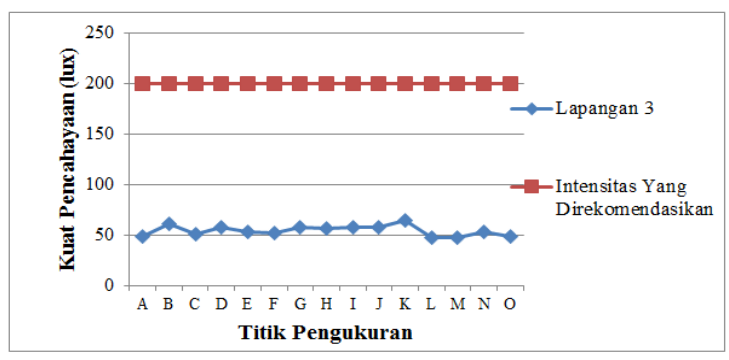

Gambar 12. Grafik kuat pencahayaan lapangan 3

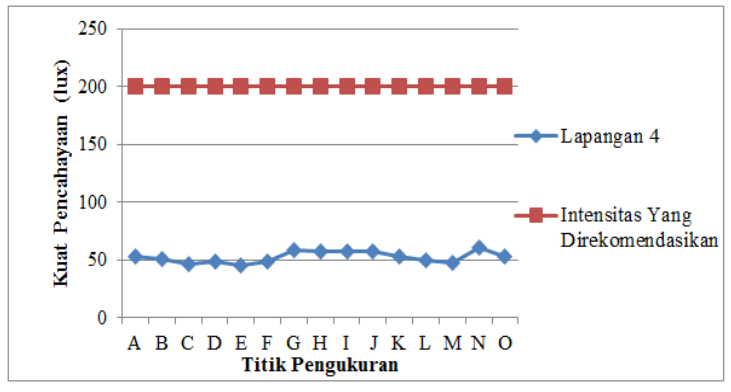

Gambar 13. Grafik kuat pencahayaan lapangan 4

Dari grafik pada gambar 9 sampai dengan gambar 13 dapat diketahui bahwa untuk seluruh daerah lapangan planet futsal Rumbai Pekanbaru, pada titik yang diukur nilai kuat pencahayaan belum mencapai nilai yang direkomendasikan oleh SNI 16-
7062-2004 untuk lapangan futsal yang dibutuhkan intensitas atau kuat penerangan 200-300 lux.

Kuat pencahayaan rata-rata untuk seluruh lapangan planet futsal Rumbai dan keempat lapangan futsal tersebut belum memenuhi standar yang direkomendasikan. Pada tabel 9 disajikan perbandingan niai hasil pengukuran dengan standar yang direkomandasikan.

Tabel 9. Perbandingan Hasil Pengukuran Dengan Standar Rekomendasi SNI 16-7062-2004

\begin{tabular}{|c|c|c|c|c|}
\hline \multirow{2}{*}{$\begin{array}{c}\text { Area yang } \\
\text { Diukur }\end{array}$} & \multicolumn{2}{|c|}{$\begin{array}{c}\text { Intensitas Penncahayaan } \\
\text { (lux) }\end{array}$} & \multirow{2}{*}{$\begin{array}{c}\text { Selisih } \\
\text { (lux) }\end{array}$} & \multirow{2}{*}{ Keterangan } \\
\cline { 2 - 3 } & Pengukuran & Standart & & \\
\hline Lapangan 1 & 52,95 & 200 & $-147,05$ & Tidak memenuhi \\
\hline Lapangan 2 & 50,26 & 200 & $-149,74$ & Tidak memenuhi \\
\hline Lapangan 3 & 54,28 & 200 & $-145,72$ & Tidak memenuhi \\
\hline Lapangan 4 & 54,16 & 200 & $-145,84$ & Tidak memenuhi \\
\hline
\end{tabular}

Pada tabel 9 perbandingan hasil pengukuran dengan standart SNI 16-7062-2004 di dapat pemerataan pencahayaan dengan intensitas pencahayaan rata-rata pengukuran dibagi dengan minimal yang di rekomendasikan. Analisa pemerataan pencahayaan pada lapangan planet futsal Rumbai Pekanbaru harus mendapat nilai lebih besar sama dengan 0,8 lux dari (rata-rata pengukuran dibagi minimal yang direkomendasikan) seperti pada tabel 10.

Analisa pemerataan $=\frac{\text { Rata }- \text { rata Pengukuran }}{\text { Intensitas Yang direkomendasikan }}$

Tabel 10. Analisa Pemerataan Pencahayaan

\begin{tabular}{|c|c|c|}
\hline Area & Rata-rata/Minimal & Keterangan \\
\hline Lapangan 1 & 0,26 lux & Belum merata \\
\hline Lapangan 2 & 0,25 lux & Belum merata \\
\hline Lapangan 3 & 0,27 lux & Belum merata \\
\hline Lapangan 4 & 0,27 lux & Belum merata \\
\hline
\end{tabular}

\subsection{Intensitas Penerangan di Lapangan Planet Futsal Rumbai Pekanbaru}

Lumen yang dibutuhkan untuk masing-masing lapangan pada lapangan planet futsal indoor, yang sesuai standart sebuah lapangan olah raga futsal dari persamaan 2 adalah sebagai berikut [8] :

$$
\begin{aligned}
\Phi_{\text {masing-masing lapangan }} & =E \times A \\
& =200 \text { lux } \times 416 \mathrm{~m}^{2} \\
& =83.200 \text { lumen }
\end{aligned}
$$

Dari kondisi eksisting penggunaan lampu pada lapangan planet futsal indoor Rumbai pada keseluruhan lapangan memakai 100 buah lampu, 
dengan 2 jenis lampu yang digunakan yaitu jenis Compact Flourescent Lamps (CFL) 70W/4400 lm merek Philips dan Compact Flourescent Lamps (CFL) 52W/3230 lm merek Philips, setiap jenis lampu di pasang secara selang seling untuk masingmasing lapangan. Jika menggunakan lampu jenis Compact Flourescent Lamps (CFL) 70W/4400 lm 25 buah, sesuai posisi atau kondisi lapangan saat ini, maka :

$$
\begin{aligned}
\mathrm{E}= & \frac{N \times n \times L L \times C U \times L L F}{A} \\
& =\frac{25 \times 1 \times 4400 \times 0,60 \times 0,87}{416} \\
& =138,02 \mathrm{lux}
\end{aligned}
$$

Dari kondisi diatas ternyata lapangan planet futsal Rumbai belum memenuhi standart (200 lux) dari sisi pencahayaan untuk lapangan olah raga futsal, maka perlu di desain kebutuhan lampu untuk ruangan tersebut jenis lampu Compact Flourescent Lamps (CFL) 100W/6285.

$$
\begin{aligned}
\mathrm{N} & =\frac{(E \times A)}{(L L \times C U \times L L F)} \\
& =\frac{83200}{(6285 \times 0,60 \times 0,87)} \\
& =25,35 \mathrm{titik}
\end{aligned}
$$

Titik jumlah lampu yang akan dipasang pada ukuran $16 \times 26 \mathrm{~m}^{2}$ untuk masing-masing lapangan planet futsal Rumbai Pekanbaru dibulatkan menjadi 25 titik lampu [1].

\subsection{Simulasi Menggunakan Dialux}

Hal pertama dilakukan adalah mesimulasikan kondisi lapangan planet futsal indoor Rumbai sesuai dengan spesifikasi yang ada ke dalam perangkat lunak Dialux. Dengan 25 buah lampu Philips yang berfungsi untuk pencahayaan lapangan.

\subsubsection{Simulasi Pertama Pada Kondisi Eksisting}

Pada simulasi yang pertama dilakukan untuk mencocokkan data hasil pengukuran dengan alat ukur yang di input pada tabel 4 sampai dengan tabel 7 hasil simulasi seperti pada gambar 14 dan gambar 15 dengan spesifikasi lampu yang tertera pada tabel 3. Keterangan :

\section{1 = Lampu Compact Flourescent Lamps (CFL) $70 \mathrm{~W} / 4400 \mathrm{~lm}$}

\section{2 = Lampu Compact Flourescent Lamps (CFL) $52 \mathrm{~W} / 3230 \mathrm{~lm}$}

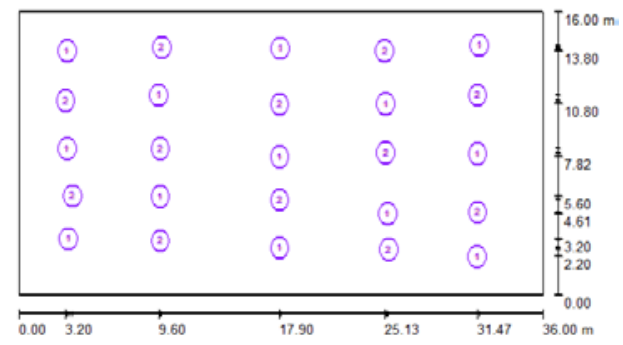

Gambar 14. Posisi lampu terhadap lapangan

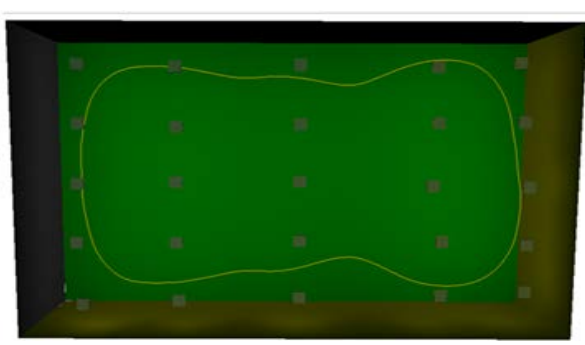

Gambar 15. Posisi lampu terhadap lapangan 3D

Dari tabel 3 dapat diketahui bahwa jenis luminaire 1 dan 2 sama yaitu Compact Flourescent Lamps (CFL) philips Essential 70W/4400 lm dan philips Helix 52W/3230 lm, tetapi dalam pemakaian lampu berbeda, hal itu yang menyebabkan luminaire maupun Wattage-nya berbeda, yang jenis kedua lebih kecil dari luminaire maupun Wattage-nya dari pada yang pertama. Hasil simulasi seperti pada gambar 16 dan gambar 17.

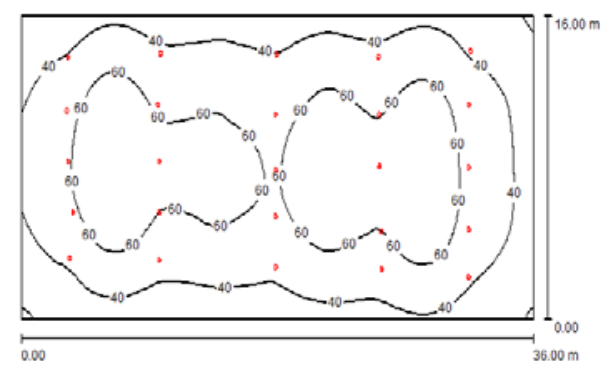

Gambar 16. Hasil simulasi

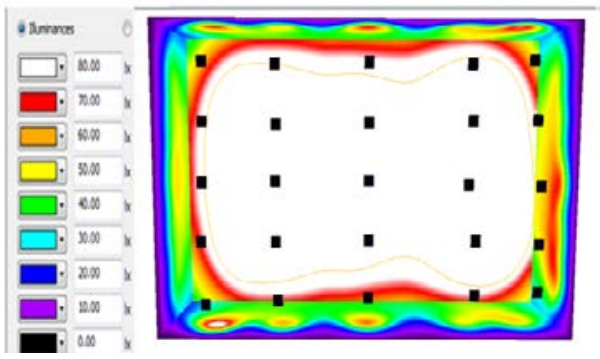

Gambar 17. Hasil simulasi 3D

Dari hasil simulasi pada gambar 16 dan gambar 17 menunjukkan pencahayaan pada lapangan planet 
futsal Rumbai Pekanbaru belum merata, kuat pencahayaan masih belum memenuhi standart rekomendasi SNI 16-7062-2004. Maka dari itu perlu dilakukan penambahan pencahayaan ulang melalui melalui simulasi perangkat lunak. Adapun perbandingan pengukuran dengan simulasi seperti pada tabel 11 .

Tabel 11. Perbandingan Pengukuran Dengan Simulasi

\begin{tabular}{|c|c|c|c|c|}
\hline No & Ruangan & $\begin{array}{c}\text { Tingkat } \\
\text { Pencahayaan Hasil } \\
\text { Pengukuran } \\
\text { (Lux) }\end{array}$ & $\begin{array}{c}\text { Tingkat } \\
\text { Pencahayaan } \\
\text { Hasil simulasi } \\
\text { (Lux) }\end{array}$ & $\begin{array}{c}\text { Tingkat } \\
\text { Pencahayaan Yang } \\
\text { direkomendasikan } \\
\text { (Lux) }\end{array}$ \\
\hline 1 & Lapangan 1 & 52,95 & 60 & 200 \\
\hline 2 & Lapangan 2 & 50,26 & 60 & 200 \\
\hline 3 & Lapangan 3 & 54,28 & 60 & 200 \\
\hline 4 & Lapangan 4 & 54,16 & 60 & 200 \\
\hline
\end{tabular}

\subsubsection{Simulasi Kedua Dengan Penambahan Daya Lampu}

Dari gambar 16 dan gambar 17 untuk mendapatkan kuat pencahayaan rata-rata sebesar 200 lux maka diperlukan penambahan daya lampu. Adapun tahapan demi tahapan yang dilakukan untuk mendapatkan hasil dengan mensimulasikan jenis lampu :

1. Compact Flourescent Lamps (CFL) 70 W sebanyak 25 buah untuk masing-masing lapangan. Hasil yang didapatkan belum memenuhi.

2. Compact Flourescent Lamps (CFL) 80 W sebanyak 25 buah untuk masing-masing lapangan. Hasil yang didapatkan belum memenuhi.

3. Compact Flourescent Lamps (CFL) 90 W sebanyak 25 buah untuk masing-masing lapangan. Hasil yang didapatkan belum memenuhi.

4. Compact Flourescent Lamps (CFL) 100 W sebanyak 25 buah untuk masing-masing lapangan. Hasil yang didapatkan sudah memenuhi pencahayaan rata-rata sebesar 200 lux seperti pada gambar 18 dan gambar 19.

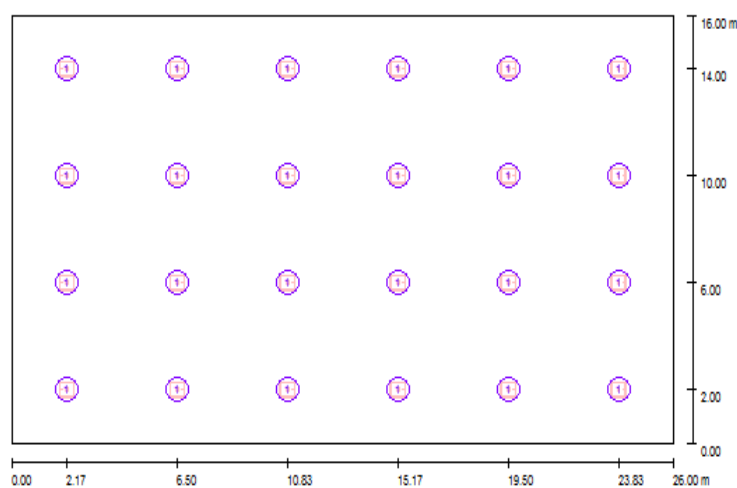

Gambar 18. Posisi lampu terhadap lapangan
Keterangan :

1 = Lampu Compact Flourescent Lamps (CFL) $100 \mathrm{~W} / 6285 \mathrm{~lm}$

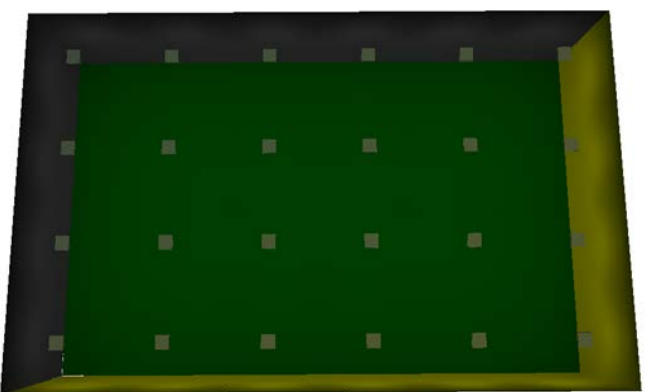

Gambar 19. Posisi lampu terhadap lapangan 3D

Dari hasil penambahan lampu dan penentuan posisi lampu dapat dilihat bahwa cahaya luminair terdistribusi maksimal di bagian lapangan futsal. Hasil simulasi seperti pada gambar 20 dan gambar 21 berikut :

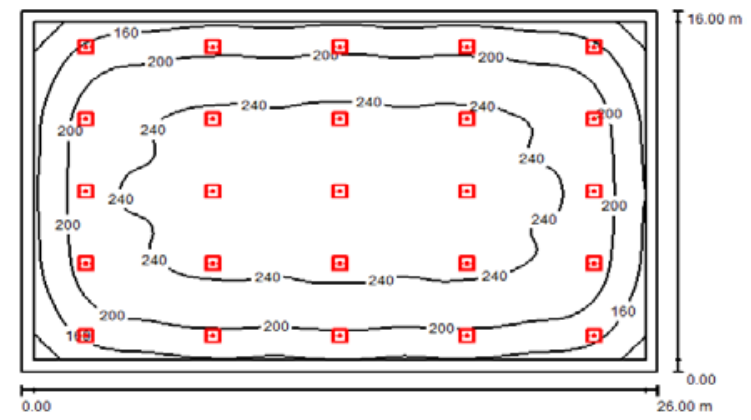

Gambar 20. Hasil simulasi

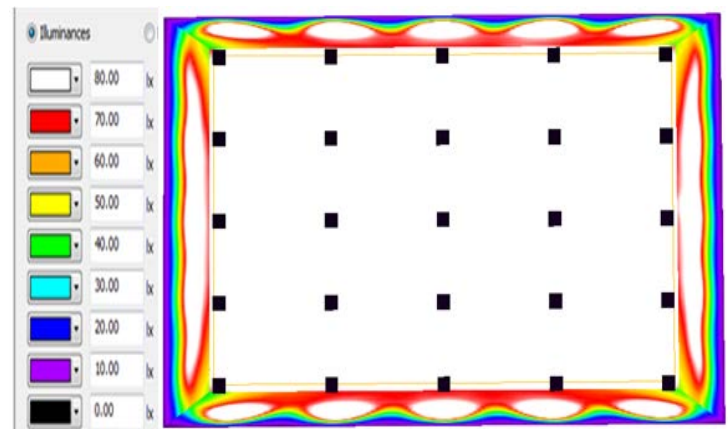

Gambar 21. Hasil simulasi 3D

Gambar 20 dan gambar 21 menunjukkan bahwa pencahayaan lapangan sudah merata dan sesuai standar rekomendasi SNI 16-7062-2004 perbandingan pengukuran dengan simulasi seperti pada tabel 12. 
Tabel 12. Perbandingan Pengukuran Dengan Simulasi

\begin{tabular}{|c|c|c|c|c|}
\hline No & Ruangan & $\begin{array}{c}\text { Tingkat } \\
\text { Pencahayaan Hasil } \\
\text { Pengukuran } \\
\text { (Lux) }\end{array}$ & $\begin{array}{c}\text { Tingkat } \\
\text { Pencahayaan } \\
\text { Hasil simulasi } \\
\text { (Lux) }\end{array}$ & $\begin{array}{c}\text { Tingkat } \\
\text { Pencahayaan Yang } \\
\text { direkomendasikan } \\
\text { (Lux) }\end{array}$ \\
\hline 1 & Lapangan 1 & 52,95 & 200 & 200 \\
\hline 2 & Lapangan 2 & 50,26 & 200 & 200 \\
\hline 3 & Lapangan 3 & 54,28 & 200 & 200 \\
\hline 4 & Lapangan 4 & 54,16 & 200 & 200 \\
\hline
\end{tabular}

\section{KESIMPULAN}

1. Hasil pengukuran intensitas pencahayaan pada lapangan planet futsal Rumbai Pekanbaru menurut standart rekomendasi SNI 16 - 7062 2004 diperoleh nilai intensitas rata-rata untuk masing-masing lapangan tersebut sebesar 52,95 lux, 50,26 lux, 54,28 lux, dan 54,16 lux. Nilai intensitas cahaya tersebut tidak memenuhi standart rekomendasi SNI 16 - 7062 - 2004 yaitu minimal 200 lux.

2. Luminasi yang dibutuhkan berdasarkan perhitungan untuk lapangan planet futsal Rumbai Pekanbaru sesuai standart yang direkomendasikan SNI 16-7062-2004 adalah 83.200 lumen, sehingga jika menggunakan jenis lampu Compact Flourescent Lamps (CFL) 70W/4400 lm, maka dipasang sebanyak $4 \times 36$ buah lampu. Bila menggunakan jenis lampu Compact Flourescent Lamps (CFL) 100W/6285 $\mathrm{lm}$, maka dipasang sebanyak $4 \times 25$ buah lampu.

3. Dari simulasi didapatkan hasil pada masingmasing lapangan diperoleh rata-rata 200 lux, dengan memilih jenis lampu philips Compact Flourescent Lamps (CFL) 100W/6235 lm sebanyak $4 \times 25$ buah.

\section{DAFTAR PUSTAKA}

[1] Harten. P. van, E.setiawan, Instalasi Arus Kuat 2, Trimitra Mandiri, Jakarta, 1983.

[2] Khrisna Yoga, Hukum Iluminasi, https:// www.academia.edu/5918711/Hukum_Iluminas i, 2017.

[3] Watkins A.J, R.K. Parton, Perhitungan Instalasi Listrik. Vol. 2, Erlangga, Jakarta, 2004.

[4] Muhaimin, Teknologi Pencahayaan, Refika Aditama, Bandung, 2001.

[5] Saputro Jimmy Harto, Tejo Sukmadi dan Karnoto, Perancangan Software Aplikasi Optimasi Penataan Lampu PJU Sebagai Upaya Penghematan Biaya Energi Listrik, Jurusan Teknik Elektro-Fakultas Teknik UNDIP, Semarang, 2005.

[6] Shciler, Interior Lighting Design, 6th ed, The Lighting Industry Federation Ltd And The Electrity, London, 1992.
[7] Sorcar, P. C, Architectural Lighting for CommercialInteriors,1sted.,WileyInterscience. https://www.amazon.com/ArchitecturalLightin gCommercial-InteriorsSorcar/dp /0471011681, 1987.

[8] Atmam, Zulfahri, Analisis Intensitas Penerangan dan Penggunaan Energi Listrik di Laboratorium Komputer Sekolah Dasar Negeri 150 Pekanbaru, Jurnal SiTekIn, Vol. 13, No.1, pp.1-8, 2015. 